\title{
Mixed Phenotype Acute Leukemia, B/T, Not Otherwise Specified
}

National Cancer Institute

\section{Source}

National Cancer Institute. Mixed Phenotype Acute Leukemia, B/T, Not Otherwise

Specified. NCI Thesaurus. Code C151992.

A very rare mixed phenotype acute leukemia, not otherwise specified in which the blasts

show clear-cut evidence of both B-cell and T-cell lineage. (WHO 2017) 